Андрій Зельницький, кандидат педагогічних наук, професор ORCID ID 0000-0002-3910-7329

Олег Заболотний, кандидат військових наук, доцент ORCID ID 0000-0001-8020-4721

Лариса Левицька,

ORCID ID 0000-0001-6575-9964

Національний університет оборони України імені Івана Черняховського

\title{
ТЕХНОЛОГІЗАЦЯ ОСВІТНЬОГО ПРОЦЕСУ ВИЩИХ ВІЙСЬКОВИХ НАВЧАЛЬНИХ ЗАКЛАДІВ
}

У статті досліджуються актуальні проблеми технологізаџії освітнього прочесу закладів вищої військової освіти та військових навчальних підрозділів закладів вищої освіти (далі-3ВО) в умовах модернізачії вітчизняної вищої військової школи, а також у зв'язку з необхідністю підвищення ефективності функціонування системи військовоі освіти та якості підготовки військових фахівців відповідно до вимог професіоналізачї сил оборони з максимальним використанням досвіду антитерористичної операцї та застосуванням передових технологій і методик підготовки здобувачів військової освіти в арміях краӥн-членів НАТО. Дослідження базується на розкритті сутності $i$ змісту структурних складників педагогічної технологї (далі - ПТ) та аналізу їх взаємозв'язків у иілісній системі технологізаиії освітнього процесу $3 B O$.

Ключові слова: технологізачія освіти; педагогічні технологї; компетентності; системність; иіле покладання; проектування; коригування.

Постановка проблеми. Технологізація освітнього процесу в системі якості підготовки військових фахівців 3 вищою освітою постає як одна 3 пріоритетних проблем військової педагогіки. Ї̈і розв'язанню присвячено багато фундаментальних і прикладних наукових досліджень, чільне місце серед яких, посідає впровадження сучасних освітніх технологій та методик.

Проведений аналіз відповідних наукових джерел свідчить про введення у науково-педагогічний обіг різних підходів до визначення сутності, змісту і структури педагогічного поняття “технологізація”, які, здебільшого, базуються на витлумаченні представниками певних наукових шкіл окремих педагогічних категорій: “освітні технології”, “педагогічні технології”, “технології навчання", “методики навчання”, що в даному контексті не відповідає принципу системного розгляду технологізації як цілісного процесу, упровадження якого в педагогічну практику має сприяти гарантуванню якості підготовки військових фахівців, формуванню в них визначених в освітніх програмах компетентностей та досягнення відповідних результатів навчання. Відтак, проблема технологізації освітнього процесу, розроблення іiі теоретичних основ і комплексного застосування педагогічних технологій в педагогічній практиці складає наукову і практичну значимість. 
Аналіз останніх досліджень і публікацій. Наукове обгрунтування технологізації освіти пропонують у своїх фундаментальних працях зарубіжні вчені: Б. Блум, Дж. Керрол, Д. Брунер, Г. Гейс, В. Коскареллі та ін.

Вітчизняну теорію та практику здійснення технологічних підходів до навчання відображено в наукових працях В. Андрущенка [1], В. Безпалька [2], А. Вітченка [3], С. Гончаренка [5], В. Докучаєвої [6], В. Кремень [8], О. Пометун [11], С. Сисоєвої [10], В. Ягупова [12], та ін.

Мета статті - дослідити сутність, зміст та взаємозв'язки основних структурних складових педагогічної технології у цілісній системі технологізації освітнього процесу закладів вищої військової освіти.

Методи дослідження. Дослідження проведене із застосуванням таких теоретичних методів: системний аналіз і синтез, індукція та дедукція, порівняння, класифікація, узагальнення й систематизація; ідеалізації та абстрагування.

Виклад основного матеріалу. Здатність системи військової освіти відповідати на нові виклики здебільшого зводиться до іiі готовності оперативно реагувати на них. Зазначена проблема набула особливої актуальності у теперішній час, пов'язаний із використанням ЗС України у зоні АТО, міжнародних операціях 3 підтримання миру ї безпеки та виявленими певними недоліками щодо якості підготовки військових фахівців. Успішному розв'язанню даної проблеми може значною мірою сприяти технологізація освітнього процесу ЗВО.

Визначення сутності, змісту i структури педагогічного поняття “технологізація" ще не знайшло свого остаточного тлумачення. На думку авторів поняття технологізації вищої освіти може бути представлене як процес теоретичного розроблення і практичного застосування сукупності певних педагогічних технологій, спрямованих на досягнення встановленого рівня сформованості у здобувачів освіти визначених компетентностей шляхом вибору та впровадження в освітню діяльність відповідних методів, засобів та організаційних форм, що мають гарантувати досягнення заздалегідь спланованих результатів навчання через чітко визначену послідовність дій. Тобто, під технологізацією можна розуміти процедуру трансформації й доцільного використання різних педагогічних технологій та їхніх елементів у реальних системах навчання при збереженні загальних компонентів і ознак технології з позицій системного й діяльнісного підходів.

Ефективність технологізованого освітнього процесу може істотно підвищуватися, якщо його введення у вищу освіту базується на основних положеннях акмеологічної науки (Б. Г. Ананьєв, Н. В. Кузьміна, А. А. Реан та ін.), що орієнтують на можливості людини, на реалізацію в освітньому процесі іiі творчого потенціалу. При цьому, найбільш результативними технологіями $€$ ті, що реалізують моделі навчання, пов'язані з освоєнням нового досвіду (М. В. Кларін). У таких технологіях успішно реалізуються ідеї гуманізації й демократизації навчання, індивідуалізації й соціалізації 
особистості, укрупнення дидактичних одиниць, активізації навчальної діяльності та рефлексії.

Тривалий час термін “технологія” залишався за межами понятійного апарату педагогіки й використовувався, здебільшого, у технократичній мові. Проте, буквальне значення цього терміну (“вчення про майстерність”) не суперечить завданням педагогіки: опису, поясненню, прогнозуванню, проектуванню педагогічних процесів. У межах технологізації освітнього процесу кожна 3 окремих педагогічних технологій, за визначенням, представленим у "Глосарії термінів з технологій освіти” (Париж, ЮНЕСКО), являє собою системний метод створення, застосування і визначення всього процесу викладання та засвоєння знань з урахуванням технічних і людських ресурсів та їх взаємодії, завдання якого - оптимізація форм освіти [4].

На наш погляд, більш адекватним щодо відповідності специфіці вищої військової школи є таке визначення поняття ПТ: педагогічна технологія - це структурно упорядкована i чітко визначена за змістом і послідовністю упровадження в навчальний процес, взаємодія суб'єктів педагогічної діяльності, що має гарантовано забезпечити визначений рівень сформованості у здобувачів військової освіти певних компетентностей відповідно до прийнятих освітніх стандартів та досягнення заздалегідь спланованих результатів навчання шляхом вибору та впровадження в освітню діяльність певних методів, засобів та організаційних форм.

Введення у науковий обіг достатньо складного за змістом, структурою та значимістю щодо якості освіти поняття “педагогічна технологія" має відповідати основним методологічним вимогам (критеріям технологічності), зокрема: концептуальності, системності, керованості, ефективності, відтворюваності. Відповідно до зазначених критеріїв технологічності основними структурними складовими ПТ, як системи, слід вважати такі 3 них: цільова, мотиваційно-акмеологічна, проектувально-планувальна, змістово-компетентнісна, комунікативно-перетворювальна, діагностичнооцінна, аналітично-моніторингова та коригувальна.

Розглянемо сутність і зміст кожної із зазначених складових [8].

1. Цільова складова.

Цілепокладання є основою для розроблення всіх інших елементів ПТ. Під цілями, як складової педагогічної технології, розуміється ідеальна модель бажаного результату щодо формування особистості із заданими якостями. Ступінь відповідності досягнутих результатів навчання цілям освіти виступає показником ефективності освітнього процесу. Цілі (навчально-виховні, розвивальні, психологічної підготовки до професійної діяльності) мають бути поставлені діагностично, а саме:

настільки точно i виразно, щоб можна було зробити однозначний висновок про ступінь їх реалізації;

існує спосіб (інструментарій) для виявлення рівня сформованості якостей особистості (компетентностей), що діагностується у ході об'єктивного контролю; 
можливе вимірювання інтенсивності розвитку якості, що діагностується; існує шкала оцінок якості, що спирається на результати вимірювання.

Діагностичні цілі безпосередньо впливають на удосконалення змісту освіти, на посилення органічних взаємозв'язків між окремими дисциплінами та формування компетентнісно-змістових міждисциплінарних модулів, на запобігання некерованому розширенню обсягу навчального матеріалу та довільних вимог щодо рівня його засвоєння тими, хто навчаються.

Подібні підходи до цілепокладання сприятимуть побудові цілком визначеного дидактичного процесу, що гарантуватиме: досягнення визначених цілей у ході освітньої діяльності; усуненню причин, що заважають ii розвитку; об'єктивності оцінки досягнень та якостей особистості; виявленню передумов, які забезпечують успішність у навчанні.

2. Мотиваційно-акмеологічна складова.

Мотиваційно-акмеологічна складова ПТ є іï рушійною силою, що розповсюджує свій вплив на всіх учасників педагогічного процесу і має надихати їх на самоосвіту, самовдосконалення, наполегливу творчу діяльність, на досягнення необхідного рівня якості освіти.

Цей процесуальний компонент поєднує в собі два ключових поняття: “мотив ” і “акмеологія”. Мотив (від лат. Moveo - рухати) - матеріальний чи ідеальний предмет, що спонукає і спрямовує на себе діяльність чи вчинок i заради якого вони здійснюються. Окрім функції спонуки і спрямованості діяльності мотив виконує також смислотворчу функцію, надаючи певний особистий смисл цілям, діям, створює усталеність інтересу до них з боку особистості, а також до аналізу обставин, що або сприяють, або перешкоджають реалізації мотиву. Мотив визначає характер пізнавальних процесів і структурує зміст сприйняття, пам'яті, мислення і т. ін.

Друге поняття - акмеологія (від грец. Асте - вершина і ...логія) - наука про закономірність розвитку та функціонування найвищої творчої діяльності людини. Основним підсумком застосування акмеології в педагогіці виступає професіоналізм, як стійка властивість особистості, що за результатами професійної освіти повністю відповідає принципу єдності особистості та діяльності.

Таким чином, мотиваційно-акмеологічний компонент педагогічної технології, як системного утворення, відіграє важливу роль у її структурі. Він органічно пов'язаний 3 іншими складовими і спонукає всіх учасників педагогічного процесу до самовдосконалення, самоосвіти, саморозвитку, досягнення на цьому шляху найвищих результатів.

3. Проектувально-планувальна складова.

Проектування являє собою заздалегідь намічену систему заходів, дій, що передбачає порядок, послідовність і терміни їх виконання у відповідності 3 визначеною метою і завданнями щодо якості підготовки військових фахівців, a caмe:

уточнення спеціальностей, відповідно до переліку галузей знань, i спеціалізацій підготовки військових фахівців; 
формування на основі нормативних вимог до якостей військових фахівців визначених в освітніх програмах компетентностей, обгрунтування компетентнісної моделі підготовки військових фахівців 3 пріоритетами практичної спрямованості;

створення дієвої системи інтелектуального, професійно-психологічного, медичного та психофізіологічного конкурсного відбору кандидатів на навчання у ВВНЗ;

проектування системи підготовки, перепідготовки та підвищення кваліфікації науково-педагогічних працівників;

розроблення змістових характеристик освітньої діяльності, що мають технологізувати втілення освітньо-професійної програми, спрямованої на досягнення встановленого рівня сформованості визначених компетентностей.

Результати проектування знаходять своє втілення в основних нормативних документах 3BВО, що регламентують навчальний процес із підготовки здобувачів вищої військової освіти - у навчальних планах та освітніх програмах.

4. Змістово-компетентнісна складова.

Зміст освіти має визначатися на основі професіографічного опису майбутньої діяльності випускника ВВН3, ВНП ВНЗ, що трансформується у визначені в освітній програмі компетентності та заздалегідь сплановані результати навчання. При цьому, поняття “компетентність” у Законі України «Про освіту» (п.15, ст.1, Розд.І) визначається як “динамічна комбінація знань, умінь, навичок, способів мислення, поглядів, цінностей, інших особистих якостей, що визначає здатність особи успішно соціалізуватися, провадити професійну та/або подальшу навчальну діяльність" [7]. За аналогією, поняття компетентність здобувача вищої військової освіти є показником якості його підготовки як доведена ним здатність i готовність до виконання функціональних обов'язків на посаді за призначенням у військах (силах) в умовах мирного і воєнного часу на основі творчого застосування здобутих знань, сформованих навичок та умінь, інших професійно важливих якостей $\mathrm{i}$ ціннісних орієнтацій відповідно до стандартів освіти [9].

Основними компетентностями здобувача вищої військової освіти $є$ такі: соціально-особистісна (морально-етична, індивідуально-психологічна, інформаційно-комунікативна, самовдосконалення); загальнонаукова, загально-професійна, військово-професійна (загальновійськова, військовоспеціальна). Кожна із зазначених компетентностей має бути диференційованою до рівня показників та критеріїв, що можуть бути об'єктивно оцінені викладачами (контролюючими особами) в педагогічній практиці.

5. Комунікативно-перетворювальна складова.

Сутність комунікативно-перетворювальної складової полягає у пї спрямованості на формування у здобувачів освіти визначених в освітній програмі компетентностей шляхом вибору та впровадження в освітню 
діяльність відповідних методів, засобів та організаційних форм, що мають гарантувати досягнення заздалегідь спланованих результатів навчання.

До основних компонентів комунікативно-перетворювальної складової ПТ можна віднести такі:

технологізація освітнього процесу, орієнтація на застосування інноваційних підходів щодо підготовки військових фахівців: суб'єктсуб'єктної взаємодії викладачів і здобувачів вищої військової освіти, інтерактивних, інформаційних та інших технологій навчання;

активне використання науково обгрунтованих методів та засобів навчання i виховання, які забезпечують поєднання фундаментальної теоретичної підготовки військових фахівців 3 системою їх практичної підготовки; перехід від екстенсивно-інформаційного та екстенсивнорепродуктивного навчання до інтенсивно-фундаментального, продуктивного;

запровадження особистісно-орієнтованих технологій навчання, створення військовим фахівцям належних умов для формування індивідуальної освітньої траєкторії, для самостійного оволодіння знаннями, самоосвіти, подальшого професійного, кар'єрного та особистого росту, удосконалення організаційно-методичних засад самостійної роботи курсантів (слухачів, студентів);

актуалізація ролі педагога як організатора самостійної розумової праці здобувачів вищої військової освіти, їх саморозвитку та самовдосконалення на засадах педагогіки співробітництва, діалогічної взаємодії, суб' єкт-суб'єктних відносин;

забезпечення інформатизації системи підготовки військових фахівців.

6. Діагностично-оцінна складова.

Основним об'єктом діагностики в межах застосування педагогічної технології є результати навчання - сукупність знань, умінь, навичок, інших професійно важливих якостей, набутих здобувачем вищої військової освіти у процесі навчання за певною освітньо-професійною, освітньо-науковою програмою, які можна ідентифікувати, кількісно оцінити та виміряти. При цьому основну увагу слід приділити застосуванню принципу валідності, що характеризується такими чинниками:

повнотою та відповідністю застосованого інструментарію суті об'єктів дослідження, тобто наскільки добре цей інструментарій визначає те, для чого призначений (стандартизовані методики, еталонні показники та критерії тощо);

чіткістю критеріїв вимірювання та оцінювання;

можливістю підтвердити результати, отримані різними способами контролю. Реальна валідність розкривається тільки в результаті накопичення матеріалу в конкретних умовах застосування.

Визначення рівня сформованості певної сукупності знань, умінь, навичок, інших якостей, набутих здобувачем вищої військової освіти під час навчання, передбачає застосування різних форм контролю (поточний, самоконтроль модульний (рубіжний), підсумковий, а також контроль під час 
державної атестації), що базується на таких принципах:

адекватність цілям та завданням навчання - відповідність змісту та форм контролю службовому призначенню військових фахівців, змісту та формам їх практичної діяльності у військах (силах);

об’єктивність - оцінка якості знань, умінь, навичок, компетентностей, виключення при цьому суб'єктивних факторів;

індивідуальність-виявлення ступеню засвоєння змісту навчання кожним слухачем (курсантом) окремо;

всебічність - спрямованість контролю на виявлення рівня знань теоретичних положень, їх розуміння, вміння творчо застосувати знання на практиці, здатність до логічного мислення;

системність - систематичний і системний контроль рівня сформованості компетентностей, у тому числі - модульний контроль рівня засвоєння окремих компетентнісно-змістових модулів.

Подібний підхід дає можливість співвіднести результати освіти із заздалегідь визначеною нормою (стандартом), спрогнозувати подальший розвиток освітнього процесу та своєчасно вплинути на якість його стану.

7. Аналітично-моніторингова складова.

Аналітично-моніторингова складова - це важливий компонент ПТ у системи управління якістю вищої військової освіти та освітньої діяльності, що формується на основі систематичного збору, обробки, аналізу, оцінювання, зберігання та оприлюднення інформації про перебіг та стан освітнього процесу, рівень його забезпечення та результати навчання з метою встановлення відповідності отриманих даних освітнім стандартам та постійного удосконалення освітньої діяльності ВВНЗ.

8. Коригувальна складова.

Регулювання (коригування) освітнього процесу здійснюється 3 метою досягнення та підтримання його оптимального стану та забезпечення необхідного рівня якості підготовки військових фахівців відповідно до вимог стандартів освіти i освітніх програм, навчальних планів тощо шляхом упровадження керівних дій у формі видання відповідних інструкцій, наказів, розпоряджень, рекомендацій, а також через моральні та матеріальні стимули. Застосування керівних дій пов'язане з різноманітними методами управління, які є інструментом впливу суб'єкту управління на об'єкт і водночас засобом їхньої взаємодії. До основних складових коригування можна віднести такі:

розроблення заходів щодо коригування військово-педагогічного процесу на основі об' єктивної оцінки результатів;

внесення змін до змісту основних структурних компонентів педагогічної технології;

прогностична діяльність - розроблення напрямів і шляхів подальшого удосконалення освітнього процесу та коригування дій.

Коригувальна складова ПТ базується на результатах якісного аналізу (самоаналізу) стану учасників педагогічного процесу, умов навчання, навчально-виховного процесу ВВН3, діяльності випускників на первинній 
посаді у військах (силах) та на результатах комплексної кількісної оцінки рівня сформованості визначених компетентностей здобувачів вищої військової освіти.

Представлені складові ПТ органічно пов'язані між собою в межах цілісної системи технологізації освітнього процесу, де провідна роль належить стандартам освітньої діяльності та вищої освіти, що є основою для планування, всебічного забезпечення та оцінювання якості підготовки військових фахівців.

Висновки. Технологізація освітньої діяльності закладів вищої військової освіти є об'єктивним процесом її еволюції, синтезом досягнень педагогічної науки і військової практики, поєднанням традиційних елементів минулого досвіду і того, що народжено суспільним прогресом, гуманізацією і демократизацією суспільства, процесом, що має забезпечувати якість освітньої діяльності і гарантувати досягнення визначеного рівня якості підготовки військових фахівців.

Технологізація, на думку авторів, являє собою процес теоретичного розроблення і практичного застосування сукупності певних педагогічних технологій, спрямований на досягнення встановленого рівня сформованості визначених компетентностей здобувачів освіти шляхом вибору та впровадження в освітню діяльність відповідних методів, засобів та організаційних форм, що мають гарантувати досягнення заздалегідь спланованих результатів навчання через чітко визначену послідовність дій. 3 використанням педагогічної технології мінімізуються довготривалі педагогічні пошуки та експромти у власній практичній діяльності, а застосовуються ретельно продумане та попередньо проаналізоване проектування освітнього процесу, в якому належне місце посідає взаємодія суб' єктів навчання.

\section{ЛІТЕРАТУРА}

1. Андрущенко В.П. Теоретико-методологічні засади модернізації вищої освіти в України на рубежі століть (за матеріалами доповіді, виголошеної на засіданні загальних зборів АПН України 23 листопада 2000 р.) // Вища освіта України. - 2001. - № 2. - С. 5-13.

2. Беспалько В.П. Слагаемые педагогической технологи / В.П. Беспалько. - М.: Педагогика, 1989. - 191 с.

3. Вітченко А.О., Осьодло В.І., Салкуцан С.М. Технології навчання у вищій військовій школі: теорія і практика: навч.-метод. посіб. / за заг. ред. професора В.М. Телелима. - К. : НУОУ ім. Івана Черняховського, 2016. - 272 с. 1998.

4. Глоссарий современного образования / Под ред. В.И. Астаховой. - Харків. : ОКО,

5. Гончаренко С.У. Український педагогічний словник. - К.: Либідь, 1997. - 376 с.

6. Докучаєва В.В. Теоретико-методологічні засади проектування інноваційних педагогічних систем : автореф. дис. д-ра пед. наук: 13.00.01 / Вікторія Вікторівна Докучаєва // Луган. нац. пед. ун-т ім. Тараса Шевченка. - Луганськ, 2007. - 44 с.

7. Про освіту: Закон України від 05.09.2017 № 2145-VIII (Відомості Верховної Ради (BBP), 2017, № 38-39, ст.380).

8. Кремень В.Г. Освіта і наука України: шляхи модернізації (Факти, роздуми, перспективи). - К.: Грамота, 2003. - 216 с. 
9. Моніторинг якості підготовки військових фахівців у вищих військових навчальних закладах та військових навчальних підрозділах вищих навчальних закладів Збройних Сил України: наук.-метод посіб. /А.М. Зельницький, О.А. Заболотний, Ю.І. Приходько та ін..; за заг. ред. І.В. Толока.: ХНУПС, 2017, - с. 98.

10. Педагогічні технології у неперервній професійній освіті: Монографія / С.О. Сисоєва, А.М. Алексюк, П.М. Воловик та ін. // За ред. С.О. Сисоєвої. - К. : ВІПОЛ, 2001. $-502 \mathrm{c}$.

11. Пометун О. Інтерактивні технології навчання: теорія, практика, досвід : методичний посібник / О. Пометун, Л. Пироженко. - К. : А.С.К., 2002. - 136 с.

12. Ягупов В.В. Компетентнісний підхід до підготовки фахівців у системі вищої освіти / В.В. Ягупов, В.І. Свистун // Наукові записки. Серія: Педагогічні, психологічні науки та соціальна робота. - 2007. - Том 71. - С. 3-8.

\section{REFERENCES}

1. Andrushchenko, V.P. (2001). Teoretyko-metodolohichni zasady modernizatsii vyshchoi osvity $\mathrm{v}$ Ukrainy na rubezhi stolit (za materialamy dopovidi, vyholoshenoi na zasidanni zahalnykh zboriv APN Ukrainy 23 lystopada 2000 r.) [Theoretical and Methodological Principles of Higher Education Modernization in Ukraine at the Turn of the Century (Based on the Materials of the Report, Issued at the Meeting of the General Meeting of the Academy of Pedagogical Sciences of Ukraine, November 23, 2000).] Vyshcha osvita Ukrainy, 5-13 (in Ukrainian).

2. Bezpalko, V. (1989). Slahaemye pedahohycheskoy tekhnolohy [Components of Pedagogical Science] M., Pedahohyka, 191 (in Russian).

3. Vitchenko, A.O., Osodlo, V.I., Salkucan, S.M. (2016). Tehnologiyi navchannya u vishij vijskovij shkoli: teoriya i praktika [Technologies of Education in Higher Military School: Theory and Practice: Tutorial Manual] K., NUOU im. Ivana Cherniakhovskoho, 272 (in Ukrainian).

4. Glossariy sovremennogo obrazovaniya [Glossary of Contemporary Education], Pod red. V.I. Astahovoy., H. OKO, 1998 (in Russian).

5. Honcharenko, S.U. (1997). Ukrainskyi pedahohichnyi slovnyk [Ukrainian Pedagogical Dictionary] K., Lybid, 376 (in Ukrainian).

6. Dokuchaieva, V.V. (2007). Teoretyko-metodolohichni zasady proektuvannia innovatsiinykh pedahohichnykh system [Theoretical and Methodological Basis For Design of Innovative Pedagogical Systems] Luhansk, Luhan. nats. ped. un-t im. Tarasa Shevchenka (in Ukrainian).

7. Pro osvity: Zakon Ukrainy vid 05.09.2017 №2145-VIII (Vidomosti Verkhovnoi Rady (VVR), 2017, № 38-39, ст.380), [The law of Ukraine on education].

8. Kremen, V.H. (2003). Osvita i nauka Ukrainy: shliakhy modernizatsii (Fakty, rozdumy, perspektyvy) [Education and Science of Ukraine: Ways of Modernization (Facts, Reflections, Perspectives)] K. Hramota, 216 (in Ukrainian).

9. Zelnytskyi, A.M., Zabolotnyi, O.A., Prykhodko, Yu.I. (2017). Monitorynh yakosti pidhotovky viiskovykh fakhivtsiv u vyshchykh viiskovykh navchalnykh zakladakh ta viiskovykh navchalnykh pidrozdilakh vyshchykh navchalnykh zakladiv Zbroinykh Syl Ukrainy [Monitoring of Training Quality of Military Specialists in Higher Military Educational Establishments and Military Educational Units of Higher Educational Institutions of the Armed Forces of Ukraine] Kharkiv, KhNUPS, 98 (in Ukrainian).

10. Sysoieva, S.O. (2001). Pedahohichni tekhnolohii u neperervnii profesiinii osviti [Pedagogical Technologies in Continuous Professional Education] Monohrafiia, K. VIPOL, 502 (in Ukrainian).

11. Pometun, O. (2002). Interaktyvni tekhnolohii navchannia: teoriia, praktyka, dosvid [Interactive Learning Technologies: Theory, Practice, Experience] metodychnyi posibnyk, K. A.S.K., 136 (in Ukrainian). 
12. Yahupov, V.V. (2007). Kompetentnisnyi pidkhid do pidhotovky fakhivtsiv u systemi vyshchoi osvity [Competency Approach to the Specialists' Training in the System of Higher Education] Naukovi zapysky. Seriia: Pedahohichni, psykholohichni nauky ta sotsialna robota, Tom 71, 3-8 (in Ukrainian).

\title{
PЕЗЮМЕ
}

Андрей Зельницкий, кандидат педагогических наук, профессор

Олег Заболотный, кандидат военных наук, доцент

Лариса Левицкая

Национальный университет обороны Украины имени Ивана Черняховского

\section{Технологизация образовательного процесса высших военных учебных заведений}

В статье исследуются актуальные проблемы технологизащии образовательного проиесса высших военно-учебных заведений и военно-учебных подразделений высших учебных заведений в условиях модернизации отечественной высшей военной школь и необходимости повышения эффективности функиионирования системы военного образования и качества подготовки военных специалистов в соответствии $c$ требованиями профессионализачии сил обороны с максимальным использованием опьта антитеррористической операции и применения передовых технологий и методик подготовки военных специалистов с высшим образованием в армиях государств-членов НАТО. Исследование базируется на раскрытии сущности и содержания структурных составляюших педагогической технологии и анализе их взаимосвязей при осуществлении учебно-воспитательного прочесса.

Ключевые слова: технологизация образования; педагогические технологии; компетентности; системность; иелеполагание; проектирование; коррекция.

\section{SUMMARY}

\author{
Andrii Zelnytskyi, \\ PhD (Pedagogical Sciences), Professor \\ Oleh Zabolotnyi, \\ $\mathrm{PhD}$ (Military Sciences), Associate Professor \\ Larisa Levickaja \\ National Defence University of Ukraine \\ named after Ivan Cherniakhovskyi
}

\section{Technologization of educational process in higher military educational institutions}

Introduction. The article deals with the current issues concerning the technologizational process conduct at the higher military educational institutions, and highlights the issues on the ways of training the military students taking into account the experience gained in the antiterrorist operation as well as the application of NATO educational training methods.

Purpose. The purpose of the article is to study the essence, content and relations of the main functional elements of the pedagogical technology in the integral system of technological process of the higher military educational institutions.

Methods. Theoretical methods such as analysis and synthesis, induction and deduction, comparison, classification, generalization and systematization, idealization, abstraction were used during the research. 
Results. The essence, content and structure of the following pedagogical categories such as: "pedagogical technologies", "competencies", "goal setting”, "designing", "adjusting" are also considered in the article. The research reveals the essence and content of the functional elements of the pedagogical technology and the analysis of their interrelations in the educational process.

Originality. Definitive and comparative analysis of technologisation of educational process in higher military educational institutions has been provided.

Conclusion. The article deals with the defining analysis of general scientific concepts such as technological process in the higher military educational institutions. It is stated that technology of higher military education is a process of theoretical development and practical application of certain pedagogical technologies, where "pedagogical technology" as a systematic, conceptual, normative, variation description of the activities of teacher and student, aimed at achieving the general educational goal is the key concept.

Key words: technology of education; pedagogical technologies; competencies; consistency; goal-setting; design; adjustment. 